\title{
АЛЕКСАНДР КУЛИШЕР О ДЕМОГРАФИЧЕСКОМ БУДУЩЕМ РОССИИ
}

\author{
МАРК ТОЛЬЦ
}

\begin{abstract}
На рубеже 1920-х и 1930-х годов А.М. Кулишер написал три статьи, посвященные проблемам демографической динамики некоторых стран мира, которые были напечатаны в наиболее солидной и широко читаемой газете русской послереволючионной эмиграции - «Последние новости» (Париж). В них впервые в предсказании демографического будущего России использовалась общая схема демографических изменений, ныне известная как концепция «демографического перехода» или «демографической революции». В настоящей публикации приведень тексть этих статей, недоступные современному читателю, которые предваряются предисловием и дополнень комментариями к ним. В предисловии отмечены важные особенности статей А.М. Кулишера в контексте развития демографии того периода и нацеленность их автора на предвидение будущей динамики населения России.
\end{abstract}

Ключевые слова: история демографии, демографический переход, демографическая револючия, демографическая динамика, рождаемость, смертность, население России, Александр Михайлович Кулишер (1890-1942).

В ходе исследования вклада семьи Кулишеров в теорию демографии удалось обнаружить три забытые статьи самого младшего ее представителя - А.М. Кулишера, посвященные проблемам демографической динамики. Они опубликованы на рубеже 1920-х и 1930-х годов в наиболее солидной и широко читаемой газете русской послереволюционной эмиграции - «Последние новости» (Париж), одним из ведущих сотрудников которой был их автор. В них впервые в предсказании демографического будущего России использована общая схема демографических изменений, ныне известная как концепция «демографического перехода» или «демографической революции».

Сегодня мы уже знаем, что Кулишер был одним из пионеров теории демографического перехода, концепция которой была им представлена в публикациях первой половины 1930-х годов на немецком и французском языках [Вишневский, Тольц 2015]. Написанные до того газетные статьи, явились необходимым этапом на пути, который привел его к успешному формулированию этих теоретических положений. Они, несомненно, заслуживают републикации, которая и предпринята нами (см. ниже). Прежде, чем перейти к анализу найденных текстов, необходимо сделать несколько предварительных замечаний для того, чтобы лучше понять причины их имплицитной нацеленности на предсказание демографического будущего России, а также некоторые обстоятельства, способствовавшие формированию взглядов Кулишера на демографические процессы.

МАРК ТОЛЬЦ (mtolts@huji.ac.il), ИЕРУСАЛИМСКИЙ УНИВЕРСИТЕТ, ИЗРАИЛЬ. (ПРЕДИСЛОВИЕ, ПОДГОТОВКА ТЕКСТОВ И ПРИМЕЧАНИЯ)

АЛЕКСАНДР КУЛИШЕР (1890-1942).

СТАТЬЯ ПОСТУПИЛА В РЕДАКЦИЮ В АПРЕЛЕ 2018 Г. 


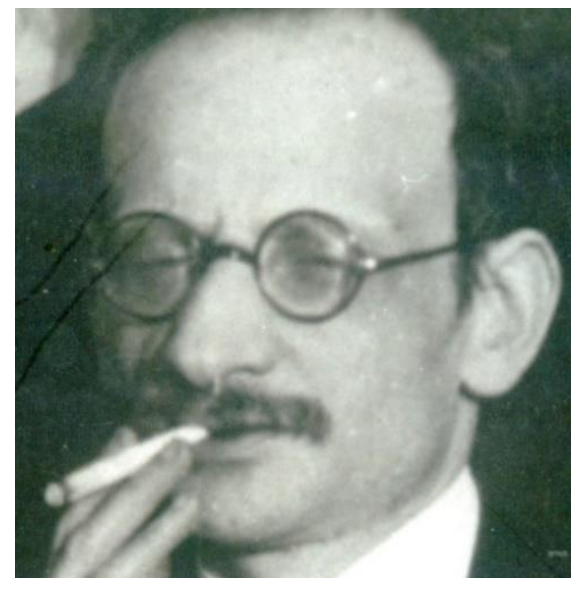

Александр Кулишер, 1927 г.

Послереволюционная русская эмиграция, к которой принадлежал Кулишер, смогла поддерживать в изгнании высокий уровень интеллектуальной активности (см., например, [Раев 1994]). Конечно, бывших граждан России, оказавшихся за ее пределами, живо интересовало положение на покинутой родине и перспективы ее развития. При этом идеи сторонников особого пути развития России - тут надо, прежде всего, назвать евразийцев получили достаточно большую популярность. Но известно, что отец А.М. Кулишера, видный ученый и публицист М.И. Кулишер, еще в конце 1870-х годов впервые выступил против тогдашних адептов «самобытности» [Тольц 2015]. Он считал, что «общая схема движения одна и та же для всех народов» [Кулишер 1887: Х]. Конечно, русских послереволюционных эмигрантов интересовали не только общие перспективы развития их страны, но и ее демографическое будущее, от которого многое зависело. Здесь А.М. Кулишер показал себя верным последователем отца - в публикуемых статьях он, в отличие от многих именитых современников (об этом см. ниже), опирался на универсальность закономерностей демографического развития в предсказании будущей динамики населения России.

Если несомненно, что направленность Кулишера на поиск универсальных закономерностей идет от отца, то определенного ответа на вопрос об истоках его демографических представлений у меня пока нет. В этой связи можно указать только на его непосредственную связь с первым американским исследователем, отметившим некоторые общие закономерности развития населения, которые много позднее вошли в концепцию демографического перехода. Им был известный социолог Э.А. Росс, который настойчиво, но, впрочем, безуспешно - он направил рекомендации в восемнадцать адресов - пытался найти место для Кулишера в одном из университетов США в начале его эмиграции [Дойков 2009: 124]. Известно, что они обменялись письмами в 1922 г. [Scifres 1964: 52]. Росс справедливо называется одним из пионеров в истории формирования теории демографического перехода [Hodgson 1993: 7]. В книге, опубликованной им еще в начале прошлого века, он отмечал, что падение смертности обгоняет снижение рождаемости, и это приводит к периоду ускоренного роста населения [Ross 1909: 36]. Позднее Кулишер будет постоянно повторять данное положение в своих публикациях. Однако пока не найдено подтверждение его знакомства именно с той книгой Росса, где впервые это было отмечено, 
хотя другие его работы А.М. Кулишер неоднократно цитирует в монографии, опубликованной в соавторстве с братом Е.М. Кулишером [Kulischer, Kulischer 1932].

После этих необходимых предварительных замечаний можно непосредственно перейти к анализу содержания публикуемых ниже статей. Первая из них является во многом продолжением рассказа о Всемирной конференции по народонаселению, состоявшейся в Женеве в 1927 г., которой Кулишер ранее посвятил специальную публикацию в той же газете [Юниус (Кулишер) 1927; см. также Тольц 2017]. Информационным поводом для этой статьи явилось появление данных о резком снижении уровня рождаемости и естественного прироста в Англии [Юниус (Кулишер) 1928]. Кулишер в ней пишет: «Развитие показывает, что население Англии, равно как и ряда других стран: Швеции, Швейцарии, Германии и, по всей вероятности, Соед. Штатов Америки явно переходит к тому состоянию неподвижности, в котором до мировой войны пребывало одно только население Франции. <...> Речь идет о неподвижности на основе низкой рождаемости и низкой смертности: в этом то и заключается новизна данного явления в истории человеческого рода».

Кулишер также отмечает: «Огромной рост населения европейских стран в XIX веке объясняется не увеличением рождаемости, а исключительно уменьшением смертности». При этом он демонстрирует достаточно четкое представление о демографическом переходе, когда, опираясь на выводы из доклада, представленного на женевской конференции голландским демографом Х.В. Метхорстом (в написании Кулишера Метгорст), пишет: «Большие приросты населения следует рассматривать, в сущности, как переходный период (выделено мною - М.Т.), когда успехи гигиены и общей культуры уже привели к сильному уменьшению смертности, но еще не наступило уменьшение рождаемости, которое, как показывает опыт всех стран, следует по пятам за этими успехами». Кулишер хорошо знал и особенности предшествующей, допереходной фазы, когда, по его словам, наблюдалось «состояние неподвижного числа населения», которое «было весьма обычным, можно думать нормальным состоянием человечества в течение громадных эпох истории». Таким образом, он уже в своей первой статье, посвященной демографической динамике, демонстрирует понимание общей схемы развития населения переход от состояния относительного равновесия при высоком уровне рождаемости и смертности к новому состоянию относительного равновесия при низком уровне рождаемости и смертности, между которыми находится период ускоренного демографического роста.

Кулишер поясняет, что при высокой рождаемости и смертности, господствовавшей на протяжении большей части истории человечества, обычно число выживших детей в семье было весьма невысоким. Отметим, что эта особенность традиционного режима воспроизводства была достаточно четко описана его старшим братом, выдающимся историком-экономистом И.М. Кулишером, в «Истории экономического быта Западной Европы» [Кулишер 2004: 225, 227]. Конечно, А.М. Кулишер был знаком с классическим исследованием брата, а значит здесь наследует представление члена своей знаменитой семьи о демографических реалиях прошлого. Но огромная эрудиция позволяет ему найти у А. Смита свой пример для иллюстрации отмеченного, которого нет у старшего брата. К сожалению, и после работ братьев Кулишеров ошибочные представления, отрицающие 
бытование в прошлом в семьях малодетности при высокой рождаемости, еще долго продолжали требовать борьбы с ними [Вишневский 2005: 185].

А.М. Кулишер в рассматриваемой статье затрагивает также проблему мотивации прокреативного поведения, подчеркивает его зависимость от стадии развития человеческого общества. Он отмечает специфическое отношение к ценности детской жизни в традиционном обществе, когда упоминает «русских крестьянок старого времени, вечно беременных и вечно мечтавших о том, чтобы “Бог прибрал” кого-нибудь из детей». В этом он предвосхищает выводы современных нам исследователей [Вишневский 2005: 257-281]. Продолжая тему мотивации прокреативного поведения, Кулишер пишет: «Усиление "материнского инстинкта" в смысле заботы о благополучии детей, - прежде всего о спасении их жизни, - есть как раз явление новейшего времени: оно и проводит к уменьшению детской смертности, но тот же “материнский” и вообще "родительский" инстинкт является одним из стимулов уменьшения рождаемости».

Констатировать уже произошедшие демографические изменения - не значит видеть в них универсальную схему развития населения. Так, уже упомянутый Метхорст, который в своем докладе рассмотрел показатели для 55 стран, включая Россию, ничего не сказал о ее демографических перспективах. В интерпретации Метхорста схема демографического перехода не играла роль инструмента, пригодного для предвидения будущего стран, которые еще не совершили демографический переход, а значит не получила завершения, точнее - необходимой универсальности. Это сделал Кулишер, впервые придавший теории демографического перехода необходимую для ее завершения универсальность, которую он использовал для предсказания демографического будущего России.

Характеризуя современную ему демографическую ситуацию на покинутой родине, Кулишер уже в 1928 г. писал: «Россия находится еще сейчас в довольно ранней стадии этого [переходного] процесса. Ускорение роста русского населения в конце XIX и начале XX века ... объясняется всецело уменьшением смертности, упавшей за вторую пол. XIX в.». Однако на основании универсального понимания направления демографических изменений, Кулишер определенно предполагал: «Несомненно, в России предстоит дальнейшее уменьшение смертности, но нет основания ожидать, что и она будет избавлена от уменьшения рождаемости».

Чтобы лучше оценить значение этого вывода Кулишера, полезно сравнить его с видением перспектив развития населения России в статье ведущего американского демографа тех лет У. Томпсона, признанного первопроходца теории демографического перехода [Szreter 1993: 661]. В этой статье, которая появилась через год после статьи Кулишера, Томпсон предполагал, что Россия, благодаря своим просторам, может надолго сохранить высокие темпы роста населения [Thompson 1929]. Обобщение Томпсона было менее универсальным и применительно к России оказалось ошибочным.

Информационным поводом для публикации второй статьи Кулишера, посвященной проблемам демографической динамики, стало появление первых результатов новой переписи населения Великобритании. Они отразили явное замедление темпов роста населения, характерное для той продвинутой фазы демографического перехода, которой оно достигло [Юниус (Кулишер) 1931]. Много позднее один из сотрудников «Последних 
новостей» так вспоминал необычную способность Кулишера находить нужный ему для работы материал: «Ни одна строка, ни в одной газете на многих языках мира, если она могла быть ему полезной, не ускользала от его внимания. Когда он все это читал, никто не знал. Знания, информация, сведения от вопросов текущей политики до общественных наук и учений - все это, как губкой, всасывалось А.М. Кулишером» [Мейснер 1966: 201].

Для данной статьи Кулишера таким необходимым материалом явилась газетная публикация ведущего английского демографа того времени А. Карр-Саундерса, в которой тот обсуждал результаты новой переписи в своей стране [Carr-Saunders 1931]. Итоги британской переписи он рассматривал на фоне демографической ситуации в разных частях мира. При этом она содержала специальный раздел, посвященный населению России. Обращение к статье Карр-Саундерса позволило многое рассказать. Однако Кулишер далеко не во всем соглашается со своим маститым английским коллегой. В главном же, на что направлен интерес Кулишера, - демографическое будущее России - он определенно расходится с Карр-Саундерсом.

Английский демограф не находил общих закономерностей в демографическом развитии Западной Европы и России, рассматривал российские условия, как «азиатские». Он не видел в российской демографической ситуации 1920-х годов одну из стадий демографического развития, подобную той, на которой когда-то находились и страны Западной Европы.

Напротив, Кулишер в своей статье продолжает твердо придерживаться универсальной схемы демографического развития. Потому он, возражая английскому демографу, твердо отвергает такое различие: «Противоположение “Европы” и “Азии” тут едва ли более правильно, чем во всех подобных случаях». Говоря о демографических перспективах России Кулишер прозорливо пишет: «Эта стадия [быстрого роста в России] должна продолжаться до того момента, когда падение рождаемости начнет нагонять падение смертности. Все дело в том, чтобы достигнуть этого момента, без катастрофических истреблений человеческих жизней. Сам по себе, этот момент должен рано или поздно наступить». К сожалению, через год демографическая катастрофа разразится - придет голод 1932-1933 гг., который поразит все хлебопроизводящие районы CCCP, а еще до того катастрофа придет в Казахстан.

В то же время Кулишер разделяет отрицательную оценку, данную Карр-Саундерсом утверждениям московских пропагандистов об имманентном для советского строя быстром росте населения. Согласно их толкованию работ К. Маркса, снижение рождаемости - это лишь удел капиталистического общества, тогда как при социализме население должно быстро расти. Хорошо известно, что этот «социалистический закон народонаселения» впоследствии еще многие десятилетия будет тормозить развитие советской демографии (см., например, [Волков 2014: 521]). Кулишер же, с присущим ему чутьем на идеологические повороты в большевистской России, показал читателям «Последних новостей» несостоятельность этой псевдонаучной догмы еще в тот момент, когда она только входила в канон советских пропагандистов.

Точка зрения Кулишера на демографические перспективы России вызывала резкое неприятие среди оппонентов «Последних новостей», конкурировавших с этим изданием за 
влияние на умы российской послереволюционной эмиграции. Так, нападая на него, другая парижская газета «Возрождение» издевательски упоминала именно демографические воззрения ученого: «Говорили, будто Кулишер - бывший профессор военного времени, окончивший ускоренные научные курсы вместо пятилетки в два года. Биографы утверждали, кроме того, что Кулишер - бывший друг Шпенглера, внук Фейербаха и приемный сын Ницше. Говорили о нем также, будто его ученые работы о деторождаемости в России получили чрезвычайно широкую известность в крупных университетских центрах Конотопа, Винницы, Белой Церкви» [Псевдонимы ... 2016: 309].

Напротив, П.Н. Милюков, известный русский историк и политический деятель, отрицавший в принципе «особые пути» развития России [Дойков 2004: 211], кажется, вполне сочувствовал демографическим воззрениям Кулишера. Подтверждением тому является появление в «Последних новостях», направление которых всецело контролировалось Милюковым, менее чем через год после второй статьи Кулишера, новой его публикации, посвященной все той же теме [Юниус (Кулишер) 1932]. Эта статья представляет особый интерес тем, что отражает период бурного развития воззрений на население и инструментария демографических исследований на рубеже 1920-х и 1930-х годов.

«Похоже на то, что демографическая наука вступает в новую стадию», - писал в новой статье Кулишер. При этом он упоминает исследования двух немецких демографов Р.P. Кучинского и Э. Кана. Тут у современного читателя, естественно, возникает вопрос: почему рядом с Кучинским, автором хорошо известных классических работ, появляется имя Кана, незнакомое сегодня даже большинству специалистов? Напомним, что Кучинский в 1928 г. опубликовал на английском языке первый том своего фундаментального труда «Баланс рождений и смертей», посвященный странам Западной и Северной Европы [Kuczynski 1928]. Именно этот том имел в виду Кулишер, когда впервые упомянул Кучинского в своей предыдущей статье. Однако второй том исследования Кучинского, посвященный странам Восточной и Южной Европы [Kuczynski 1931], был опубликован в США только за несколько месяцев до написания третьей статьи Кулишера и, вполне вероятно, еще не дошел до него в Париже. Потому у Кулишера не было возможности использовать показатели, рассчитанные Кучинским (коэффициент суммарной рождаемости и нетто-коэффициетнт воспроизводства населения), для сравнения ситуации в России с другими странами мира при помощи этой системы измерителей.

В тоже время, между появлением первого и второго томов исследования Кучинского, в 1930 г., была опубликована книга Кана «Международная забастовка рождаемости» [Kahn 1930]. Ее автор был социально ориентированным экономистом. Это отражал уже подзаголовок его книги о рождаемости: «Масштаб, причины, последствия, контрмеры». Много лет спустя ведущий польский демограф Э. Россет писал об этой книге: «Хотя Кан не был демографом, он высказал много верных мыслей, значение которых мы можем полностью оценить сегодня, оглядываясь назад» [Россет 1968: 281].

В книге Кана были приведены его оценки уровня рождаемости для многих стран мира, включая Россию, которые привлекли внимание современников (см., например, [Correspondent 1931]). С ними и знакомит Кулишер читателя. Но Кан в своей книге исходил 
из числа рождений на один брак для данного календарного периода. То, что этот показатель занижает оценку уровня рождаемости, т.к. не принимает во внимание распадение брачных союзов, Кучинский докажет только через пять лет после публикации книги Кана [Kuczynski 1935: 38]. На русском языке критика, данная Кучинским, была подробно представлена Б.Ц. Урланисом [2007: 91]. Однако приведя ее, этот известный ученый в той же работе всетаки использует данный грубый показатель в своих историко-демографических изысканиях, когда отсутствуют другие возможности для анализа [Урланис 2007: 93-94].

Впрочем, Кулишер в своей статье проявляет определенную осторожность, отмечая в ее конце, что упомянутые «методы исчисления ... вызывают и возражения, также не лишенные оснований». Стоит процитировать и самого Кана: «В данный момент кажется, что все говорит о сокращении населения. Однако никто не может знать, каких размеров достигнет это движение и как долго оно будет длиться, ибо привычки и взгляды людей так же трудно предвидеть, как и непосредственное влияние развития медицины на увеличение шансов на дожитие; это всегда нужно подчеркивать» [Kahn 1930: 208; цит. по Россет 1968: 281]. Действительно, бэби-бум в странах Запада, как и последствия открытия антибиотиков для всех стран мира оказались непредвиденными.

А вот предвидение Кулишера, данное в его третьей статье, сбылось. Ведь в ней, по существу, главный спор идет с мнением о наличии в России «неограниченного человеческого материала», который Сталин «бросает в топки своих “социалистических" заводов: уже этого-то добра, - русского народа, - всегда хватит». Возражая исповедующим данное заблуждение, которое разделял и сам большевистский вождь, Кулишер писал: «то огромное количество "рабсилы", которое пока находится, - вернее, находилось, - в распоряжении Сталина, представляет собою чисто временное явление». И опять был прав!

Знакомство с тремя публикуемыми статьями А.М. Кулишера показывает, что он был едва ли не первым, кто ясно осознал и последовательно применил для истолкования как современных ему, так и будущих тенденций воспроизводства населения общую схему, известную сегодня как теория «демографического перехода» или «демографической революции». Именно исходя из этой концепции, он сумел верно предсказать демографическое будущее России. Развитие ее населения в XX веке, действительно, пошло по тому пути модернизации, который на рубеже 1920-х и 1930-х годов предвидел этот замечательный ученый (см., например, [Демографическая модернизация ... 2006]).

Публикуемые тексты статей приводятся в соответствии с правилами современной орфографии при сохранении основных особенностей пунктуации автора. Написание личных имен и географических названий соответствует тому, как они были первоначально напечатаны. Все примечания, в том числе данные внутри текстов статей, подготовлены мною. Копии статей стали доступны благодаря усилиям моего друга профессора Ш. Штампфера, за что я ему очень признателен. Фото А.М. Кулишера предоставлено архивом Института Жаботинского в Израиле, сотрудникам которого я также глубоко благодарен. 


\section{«ВЫМИРАНИЕ»}

\section{Юниус [Кулишер А.М.] \\ Последние новости (Парижс). 1928. 8 февраля: 2.}

Мне приходилось писать по поводу женевской конференции о народонаселении (см. [Юниус (Кулишер) 1927]), на которой были приведены исчерпывающие фактические данные о развитии этого «вопроса всех вопросов» за последнее время и разыгрался резкий спор между сторонниками дальнейшего уменьшения рождаемости, опасающимися перенаселения земного шара, и сторонниками увеличения рождаемости, опасающимися вымирания наиболее культурных рас и народов. Выражение «сторонники» того и другого тут нужно понимать, конечно, весьма условно. В Женеве спорили ученые, задача которых заключалась прежде всего в том, чтобы правильно поставить вопрос и определить направление фактически происходящих стихийных процессов, очень мало поддающихся изменению путем воздействия той или иной пропаганды или политики. Но, разумеется, спорить о «желательности» столь сложных и глубоких явлений можно только уяснив себе предварительно в чем они собственно заключаются. К сожалению, как раз в этом вопросе громадная научная работа, проделанная в особенности за последнее время, остается почти совершенно неизвестной даже и образованной публике.

Сейчас сенсация по этому вопросу случилась в Англии, в которой за последний год рождаемость упала до «рекордной» цифры 16 на тысячу населения. Нужно заметить, что такая цифра за один год и выводы о предстоящем уменьшении населения на основании этой отдельной цифры, в действительности, представляют очень мало интереса. Статистика рождаемости и смертности имеет свои «фокусы». Еще недавно в Англии наблюдался значительный перевес рождаемости над смертностью при очень низком уровне обеих: 18 и 12 [на тысячу населения]. Знающие люди указывали, что крайне низкая смертность объясняется не только громадными успехами гигиены, - в особенности в области ухода за детьми, - но до некоторой степени является фиктивной, т.к. когда падает рождаемость, то уменьшается процент в населении маленьких детей, подверженных большой смертности; когда нынешнее поколение взрослых людей молодого и среднего возраста перейдет в разряд стариков и будет умирать, - общая смертность повысится и, вероятно, количество английского населения окажется почти неподвижным, как это уже давно случилось с французским населением. Но возможно и обратное: действительное уменьшение смертности среди лиц, не достигших половой зрелости или перешедших за нее, приводит, иногда к фиктивно низкой цифре рождаемости.

Таким образом, все рассуждения о том, что английское население в таком-то году «начнет уменьшаться» и т.п. не имеют большой ценности. Важна не сенсационная цифра одного года, а развитие за ряд лет. А это развитие показывает, что население Англии, равно как и ряда других стран: Швеции, Швейцарии, Германии и, по всей вероятности, Соед. Штатов Америки - явно переходит к тому состоянию неподвижности, в котором до мировой войны пребывало одно только население Франции.

Тут надо сделать очень существенную оговорку. Речь идет о неподвижности на основе низкой рождаемости и низкой смертности: в этом то и заключается новизна данного 
явления в истории человеческого рода. Вообще говоря, состояние неподвижного числа населения было весьма обычным, можно думать нормальным состоянием человечества в течение громадных эпох истории. Народы не увеличивались численно, как не увеличивается нормально общее число животных того или иного вида, - и по тем же причинам. В конце XVIII века Адам Смит рассказывал о своих наблюдениях над тогдашними шотландскими горцами, у которых в семье нормально рождались десять детей, из которых столь же нормально выживали двое (см. [Смит 2007: 130]). Позже подобное же «нормальное» положение можно было наблюдать в России, - и сейчас от него недалеко ушли многие части Индии, Китая и т.д. В Индии девушка, не вышедшая замуж по достижении половой зрелости, навлекает общее презрение на свое семейство и жестокие религиозные кары на своих предков в ином мире. В некоторых провинциях четверть детей формально вступает в брак в возрасте 5-10 лет. И, действительно, рождаемость в Индии достигает 40 на тысячу [населения], но и смертность еще и теперь доходит до 36 [на тысячу населения]: 1/4 часть детей умирает до достижения одного года. До 1890 года население Индии не увеличивалось вовсе: детская смертность, эпидемии и голод поддерживали «равновесие». В этом то «равновесии», лишь от времени до времени прерывавшемся эпохами исключительного экономического прогресса и роста населения или же, нужно прибавить, эпохами жестокого уменьшения населения путем голодовок и войн, вроде эпохи тридцатилетней войны и т.п., и пребывало человечество в те блаженные времена, когда никто не боялся «вымирания» и «ослабления материнского инстинкта».

Если в настоящее время в Индии имеется сильный рост населения, - вызывающий толки о «перенаселении», - то это происходит отнюдь не вследствие еще большего увеличения плодовитости индусов, а исключительно вследствие некоторого сокращения смертности, по крайней мере прекращения голода, как «нормального» периодического явления. Огромный рост населения европейских стран в XIX веке также объясняется не увеличением рождаемости, а исключительно уменьшением смертности. Согласно выводам докладчика на женевской конференции, голландского проф. Метгорста, изучившего статистику 50 стран ${ }^{1}$, большие приросты населения следует рассматривать в сущности как переходный период, когда успехи гигиены и общей культуры уже привели к сильному уменьшению смертности, но еще не наступило уменьшение рождаемости, которое, как показывает опыт всех стран, следует по пятам за этими успехами. Так именно было в частности в Англии, где история населения в особенности хорошо изучена: рост ее населения в конце XVIII и в XIX в. был результатом последовательного уменьшения смертности, несмотря на уменьшение рождаемости, обозначившееся уже начиная с 80-х гг. [XIX в.]. В Германии тот же процесс начался позже. В начале XX века она переживала период быстрого роста, и немцы кичились своей «жизненной» силой по сравнению с уже «выродившимися» французами и «вырождавшимися» англичанами и требовали на этом основании мировой гегемонии, в качестве «свежего и сильного» народа. Но после войны ${ }^{2}$ и

\footnotetext{
${ }^{1}$ В публикации предварительной версии этого доклада подробно рассматриваются данные за 1919-1923 гг. по 55 странам мира [Methorst 1927b: 123-125]. Однако в тексте доклада, позднее появившемся в томе материалов женевской конференции, основное внимание было уделено Нидерландам, и там говорится лишь о данных по 35 странам за тот же период [Methorst 1927a: 172], что, вероятно, является опечаткой.

2 Здесь и далее имеется в виду Первая мировая война и, соответственно период, предшествующий ей, когда говорится о довоенном времени.
} 
германская цифра рождаемости быстро спустилась почти до уровня французской, «стабилизационной» цифры. Россия находится еще сейчас в довольно ранней стадии этого процесса. Ускорение роста русского населения в конце XIX и начале XX века также объясняется всецело уменьшением смертности, упавшей за вторую пол. XIX в. с 37 до 31 [на тысячу населения]. И эта последняя цифра представляется еще ужасной с западноевропейской точки зрения. Но и данное уменьшение дало в результате громадные рекордные приросты населения (17, а в нек. годы 22 на тыс. [населения]) благодаря еще очень высокой рождаемости. Несомненно, в России предстоит дальнейшее уменьшение смертности, но нет основания ожидать, что и она будет избавлена от уменьшения рождаемости.

Дело в том, что материнский инстинкт, который по теории Сутерлэнда (упомянутого в статье г. Дионео в «Посл[едних] Нов[остях]» по этому вопросу; см. [Дионео (Шкловский) 1928], а также [Sutherland 1898]) является источником всякой морали - этот материнский инстинкт никак нельзя смешивать с инстинктом продолжения рода и еще менее с инстинктом максимального деторождения. Иначе образцом материнской любви и всяческой морали нужно было бы считать кролика, а в человеческом роде - упомянутых выше индийских матерей или русских крестьянок старого времени, вечно беременных и вечно мечтавших о том, чтобы «Бог прибрал» кого-нибудь из детей. Усиление «материнского инстинкта» в смысле заботы о благополучии детей, - прежде всего о спасении их жизни, - есть как раз явление новейшего времени: оно и проводит к уменьшению детской смертности, но тот же «материнский» и вообще «родительский» инстинкт является одним из стимулов уменьшения рождаемости. У французских крестьян система «двух детей» мотивируется прямо желанием оставить сыну нераздробленный участок, - но и вообще одним из мотивов сокращения деторождения является стремление обеспечить средства на воспитание имеющихся детей. Наряду с этим, конечно, появляются и чисто эгоистические мотивы, приводящие к росту безбрачия и бесплодия, - не вследствие усиления в населении эгоизма как такового, а вследствие большей расчетливости и осторожности в принятии на себя известных обязательств.

«К добру или к худу» это явление, не стану решать. Во Франции отсутствие роста населения трактуется как опасность главным образом, с точки зрения военной обороны страны. Этот мотив естественно играет меньшую роль в Англии, где сторонники стабилизации или уменьшения населения усматривают в нем единственный выход из экономических затруднений, создавшихся вследствие того, что Англия потеряла свою промышленную монополию и не может более непрерывно завоевывать новые рынки для пропитания большого количества населения путем промышленного производства на вывоз.

Вообще, сторонники «контроля над рождаемостью» обычно утверждают, что после распашки лучших полей во всех частях света рост населения должен замедлиться: если это не произойдет путем уменьшения рождаемости, то это сделают голод, войны и т.д. Представители противоположного взгляда возражают, что пока стабилизация населения путем уменьшения рождаемости происходит лишь среди некоторых, притом наиболее передовых в социальном и культурном отношениях и наиболее богатых народов. Если бы этим народам «буржуям», действительно удалось достигнуть «равновесия» на основе высокого уровня благосостояния, то этим они только вызовут вящую зависть народов 
«пролетариев», быстро размножающихся и бедствующих. Эти последние народы будут все более стремиться попасть в заповедный рай богатых стран, а запрещения иммиграции, вроде принятых сейчас Америкой ${ }^{3}$, приведут только к жестоким и кровавым конфликтам.

Как видно, это - вопрос действительно очень сложный, - вопрос, в котором более всего следует остерегаться упрощенных решений.

\section{ЦИКЛ НАСЕЛЕНИЯ}

\section{Юниус [Кулишер А.М.] Последние новости (Париж). 1931. 17 июля: 2.}

Только что опубликованные данные переписи населения в Англии всецело подтверждают прогнозы, вытекающие из того цикла эволюции населения, о котором мне уже неоднократно приходилось говорить на этих столбцах. За десять лет, с 1921 г. население Англии и Уэльса возросло с 37.886.699 до 39.947.931. Нужно заметить, что это увеличение приходится всецело на счет Англии, так как в Уэльсе, напротив, есть небольшое уменьшение вследствие переселения в Англию. Такое же уменьшение было за то же время в Шотландии и в Ирландии. Из всей территории британских островов население растет только в Англии, в собственном смысле, т.е. разумеется в английских городах. По замечанию Гарольда Кокса ${ }^{4}$, этот рост дошел сейчас уже до такой пропорции, что дальнейшее его продолжение означало бы превращение всей страны в какое-то весьма неэстетичное городское предместье. Всесильный рост города продолжается неуклонно, несмотря на промышленный застой, несмотря на безработицу. Продолжается, с известной точки зрения, еще интенсивнее, чем раньше, и когда значительная часть прироста населения страны уходила за океан, и когда горнопромышленные местечки Южного Уэльса также притягивали к себе население. Теперь все это кончилось. Население стремится только в город и, притом, во все более крупные центры, которые и растут, занимая окружающую местность, просто физически ликвидируя деревни и местечки. Ожидать изменения этой тенденции не приходится. Она может быть ослаблена только уменьшением прироста населения в целом. Это, отчасти, уже наступило.

Сейчас в Англии население в 37 миллионов увеличилось за десять лет на два миллиона; в 70-х гг. [XIX в.] население в 26 миллионов увеличилось за тот же срок на три миллиона. Иначе говоря, не только произошло значительное уменьшение размножения населения - и относительного прироста, - но это уменьшение привело к тому, что уменьшился уже и абсолютный прирост. Мало того. И такой прирост может продолжаться еще лет десять, а затем, по расчетам статистического управления, должно наступить прямое уменьшение населения. Существующая рождаемость составляет всего 16 на тысячу, вместо довоенных 26. Правда, понизилась и смертность, - и этим объясняется продолжающийся все еще рост. Но это понижение смертности отчасти искусственное, - вследствие относительно большого процента взрослых людей в населении, по сравнению с маленькими

\footnotetext{
${ }^{3}$ Имеются в виду ограничительные американские иммиграционные законы 1921 и 1924 гг.

${ }^{4}$ Его острая критика процесса урбанизации наиболее полно дана в: [Cox 1922: 46-66]. 
детьми и стариками. Когда нынешнее поколение англичан - взрослых людей начнет вымирать, оно не будет замещено нынешними детьми, так как последние для этого недостаточно [много]численны. Эти прогнозы не могут претендовать на полную точность, так как неизвестно, насколько успехи медицины могут еще увеличить среднюю продолжительность человеческой жизни. Но если исходить из существующей тенденции, она, очевидно, ведет к стационарному и даже слегка уменьшающемуся населению в Англии, как и в других странах северо-западной Европы. По мнению американского статистика Кучинского, недавно опубликовавшего крупное исследование по этому вопросу (cм. [Kuczynski 1928]) , $^{5}$ тенденция к «вымиранию» особенно сильна как раз в Англии и в Германии, - в противоположность Франции, где рост населения остановился уже задолго до войны, но зато и не наблюдается такой тенденции, ведущей «книзу», как в упомянутых двух странах, где этот рост и сейчас еще продолжается. По тем же расчетам, и в Соед. Штатах наблюдается тенденция, правда, не к «вымиранию», но к стационарности. Значительный прирост имеется еще в Италии, которая сейчас находится еще на «гребне» цикла: рождаемость и смертность уменьшаются там параллельно, не изменяя результата, в смысле прироста. Как известно, Муссолини не перестает заявлять, что Италия должна «расшириться или взорваться», что не мешает ему вести политику еще большего увеличения населения ${ }^{6}$, объявлять войну тенденции к понижению рождаемости, очевидно, с целью накопления сил для замышляемого «взрыва».

Совсем иначе обстоит дело на востоке Европы: в Польше, в Румынии и, в особенности, в России. Как отмечает проф. Карр-Саундерс, в статье по поводу результатов английской переписи (см. [Carr-Saunders 1931]), советская власть по-своему следит за данными мировой статистики и делает из них свои выводы. Недавно английскому профессору пришлось выслушать по радио поучение из Москвы по части его науки. «Марксистские» социологи разъяснили, что «великолепный» рост населения в России, «великолепное» плодородие русских баб свидетельствует о довольстве населения, тогда как падение рождаемости в капиталистических странах свидетельствует об исчезновении в населении жизненного импульса, вследствие безрадостности буржуазного строя.

По мнению Карр-Саундерса, «жизненная сила» советского населения означает не что иное, как азиатские, в отличие от европейских, условия существования и размножения населения. Азиатская рождаемость не означает, правда, быстрого увеличения, так как ей соответствует «азиатская» же смертность как хроническая, так и «катастрофическая». Но, при малейшем понижении этой смертности, получается громадный прирост.

Противоположение «Европы» и «Азии» тут едва ли более правильно, чем во всех подобных случаях. Некогда и самая «настоящая» Европа знала положение неподвижного, в общем, числа населения, при высокой рождаемости и высокой же смертности. Так, во Франции население было, в среднем, стационарным с XIV по XVII в., хотя тогда бывали «нормальные» семьи не с двумя, а с десятью детьми. То, что не забирали болезни, то

\footnotetext{
5 Р.Р. Кучинский был немецким ученым, однако большинство его демографических работ опубликовано на английском языке, в том числе и та, напечатанная в США, которую имеет в виду А.М. Кулишер.

${ }^{6}$ О пронаталисткой политике в фашистской Италии см., например, [Ipsen 1996].
} 
ликвидировали от времени до времени голод, чума и войны, приблизительно так же, как это до сих пор делается в Китае. Понижение смертности со второй половины XVIII в. и создало большие приросты населения в одной стране за другой. Страной-пионером в этом отношении, как и в отношении всякого рода «модернизации» вообще, была та же, Англия, рост населения которой считался рекордным. Маркс, которого московские демографы, повидимому, плохо читали, даже доказывал, что эта «жизненная сила» - создание капитализма, одно из капиталистических «зверств». Путем детского труда и т.п. капитализм поощряет рождаемость и нарочно создает себе тот пролетариат, который ему, капитализму, нужен. Капитализм сам заботится о том, чтобы человеческого материала всегда было слишком много, чтобы его можно было сколько угодно эксплуатировать. По аналогии, ортодоксальный марксист, в сущности, должен был бы обвинять советскую власть в том, что она сама создает тот беспощадно эксплуатируемый ею человеческий материал, который нужен ей для «индустриализации».

Объективно, однако, для такого обвинения нет основания, ибо теория Маркса по данному вопросу была вообще ошибочной. В действительности, сильный прирост населения в эпоху «расцветающего капитализма» является последствием не высокой рождаемости, как таковой, а падения смертности, при рождаемости не более высокой, чем прежде, даже уже начинающей слегка падать. Вот именно это и происходит сейчас в «модернизирующихся» восточноевропейских, южноамериканских, некоторых азиатских и африканских странах. Эта комбинация начинающей уже производить свое действие медицины и гигиены с еще совсем свежим и «наивным», в подавляющем большинстве, деревенским, по своим обычаям и психологии, населением и создает такой прирост населения, который внушает чувства нелепой «национальной гордости» и вызывает страхи у соседей. Особенность России заключается в том, что там значительный прирост населения идет непрерывно с первой половины XVIII в., - главным образом благодаря колонизации русских пространств, заменявшей, большей частью, катастрофическое истребление населения или эмиграцию.

Сейчас, однако, и Россия находится в разгаре процесса увеличения прироста, вследствие падения смертности при еще высокой, хотя уже начинающей падать рождаемости: рождаемость в 42 на тысячу [населения], (вместо довоенных 45), при смертности, упавшей до 18 [на тысячу населения] $]^{7}$, дает «рекордные» приросты.

Эта стадия должна продолжаться до того момента, когда падение рождаемости начнет нагонять падение смертности. Все дело в том, чтобы достигнуть этого момента, без катастрофических истреблений человеческих жизней. Сам по себе, этот момент должен рано или поздно наступить, - уже в силу самого факта переселения в города, куда стремится прирост населения, там же и подвергающийся известной «стерилизации»; городская рождаемость всегда ниже деревенской, - и едва ли не нормальным является такое положение, когда естественное развитие городского населения дает, само по себе, дефицит,

\footnotetext{
${ }^{7}$ Приводимые показатели для европейской части СССР за 1928 г. соответствуют воспроизведенным позднее, когда А.М. Кулишера уже не было в живых, в книге его брата Е.М. Кулишера [Kulischer 1948: 80]. А.М. Кулишер был фактическим соавтором соответствующего раздела этой монографии, что еще раз подтверждается появлением в его публикации данных цифр задолго до издания упомянутой книги.
} 
так что увеличение городского населения получается только вследствие того, что этот дефицит более чем компенсируется переселением в города. Но сам факт урбанизации населения, т.е. увеличения процента городского населения, должен рано или поздно привести к уменьшению общего прироста. Падение прироста относительного еще долго не означает падения прироста абсолютного, но затем начинает падать и этот последний, и, наконец, очевидно, должно наступить новое стационарное состояние на основе низкой рождаемости и смертности. Можно предположить, что в дальнейшем всякое удлинение человеческой жизни будет вызывать соответствующее уменьшение рождаемости. Этот процесс, вместе с тем, есть процесс «замены количества качеством». И вот почему передовым народам Европы, достигающим уже конца цикла, нет основания опасаться «жизненной силы» народов более отсталых, но идущих в конце концов по тому же пути.

\section{БУДУЩЕЕ ЧЕЛОВЕЧЕСТВА}

\section{Юниус [Кулишер А.М.] \\ Последние новости (Париж). 1932. 2 апреля: 3.}

Приходится вернуться к тому вопросу о населении, которому я посвятил уже столько фельетонов. Вопрос этот, от которого в конце концов зависит будущее современной культуры, претерпевает на наших глазах громадные изменения. То, что было гипотезой, становится установленным фактом. С другой стороны, «очевидные» факты оказываются результатами неточных статистических методов, и применение методов более точных открывает перспективы совсем иного рода.

Было время, когда остановка роста населения во Франции считалась исключением, свидетельствовавшим об особом «вырождении» французского народа в виду «застоя», вызванного французским мелкобуржуазным духом. Французские реакционеры усматривали в этом факте доказательство вредных последствий революции, разрушившей «семейственный» принцип. Им вторили реакционеры и милитаристы всех стран, вплоть до Троцкого. Этот образованный писатель и «революционный» деятель остановился в своих познаниях по данному вопросу на «довоенном» уровне и до сих пор приводит остановку роста населения во Франции, как такой факт, после которого об этом «остановившемся» народе с его «остановившимся» строем и говорить не стоит.

В отношении же остального человечества было принято за несомненное положение, что ему полагается быть перенаселенным. Военные философы и философствующие военные с великим презрением относились к тем, кто указывал на неразумность войны: причем тут разум, раз народам суждено «задыхаться» из-за отсутствия пространства, необходимого для непрерывно образующихся «излишков»? А так как эти «излишки» образуются повсюду, то суровые представители воинственных начал всегда имеют выбор: или указывать на наличность «излишков» в данной стране и требовать «неизбежной» войны, или же предостерегать против всякого поползновения данного народа уменьшить производство своих «излишков», ссылаясь на тот факт, что этот народ будет затоплен «излишками», которые непрерывно производятся у соседей. 
После войны стали замечать, что и еще некоторые народы, кроме французского, начинают проявлять тенденцию к такому же «застою» и более заинтересованы в обеспечении возможности приличного существования для своего потомства, чем в умножении количества этого потомства. Англичане, шведы, швейцарцы, - даже, удивительно, немцы, - принялись «вырождаться» с большой быстротой. Тогда национально настроенные исследователи пришли к следующему выводу. Все северные европейцы, все наиболее «передовые» нации идут постепенно к «застою». Эти нации явно потеряли биологическую «волю к жизни». Тем хуже для них. Другое дело, более свежие нации. Во-первых, итальянцы. Италия, по словам Муссолини, должна «или взорваться, или расшириться». На следующий же год цифры падающей рождаемости начали указывать как будто, что итальянский народ предпочитает некоторый третий выход. Не сметь, - приказал Муссолини. Как же вы хотите расширяться, если вы не будете увеличивать то перенаселение, на которое я так красноречиво жалуюсь?

И уж, во всяком случае, если вся Западная Европа «вырождается», тем хуже для нее. Это значит, что она будет захлестнута страшной волной с востока. Там, среди славянских народов: в Польше, а уже, в особенности, в России, идет чудовищный рост населения. Берегись Европа, - у Сталина излишек человеческого материала! В этом уверен и сам Сталин; уверены и те «переучившиеся» в эмиграции, которые открыли великую мудрость этого вождя в том, что он так «сурово» не считается с человеческим материалом, который бросает в топки своих «социалистических» заводов: уже этого-то добра, - русского народа, - всегда хватит.

Похоже на то, что демографическая наука вступает в новую стадию. Исследования Кучинского (о котором мне уже как-то приходилось говорить) ${ }^{8}$, Эрнста Кана (см. [Каһn 1930]) и др. ставят вопрос в совершенно новую плоскость. Если верить этим исследователям, то через одно-два десятилетия, а, может быть, и раньше, придется вообще прекратить разговоры об излишках человеческого материала, о «суровой» необходимости эксплуатации этого материала, который «используют» суровые властители. Придется и прекратить «пугание» одних народов «излишками» других и приступить к необычайно бережному, без всякой суровости, обращению с этим человеческим материалом, который, очевидно, никакой этой суровости терпеть более не намерен, никаким «волевым центрам» «использовать» себя не даст и на всякий разгул «волевых импульсов» отвечает быстрейшим сокращением своего собственного «воспроизводства».

Новая школа в демографии указывает прежде всего на крайнюю неточность обычных до последнего времени методов, как бы прямо рассчитанных на то, чтобы создавать неверные представления о фактическом ходе развития населения.

Возьмем простой пример. Если сравнить число рождений и число смертных случаев в Германии, то получается превышение рождаемости, - «естественный прирост», в количестве около 400000 чел. в год, - около 5 на тысячу. Это меньше, чем до войны, когда было более 800 000, - около 14 на тысячу. И национально настроенные круги этим крайне недовольны, так как воспроизводство военной силы, необходимой для завоевания

\footnotetext{
${ }^{8}$ См. предыдущую статью.
} 
«пространства», идет недостаточно быстро. Но все-таки население увеличивается, - в Германии и без того перенаселенной. И раз другие народы не хотят дать немцам нужного «пространства», - какой же тут остается выход, кроме Гитлера?

Но посмотрим на этот вопрос с иной точки зрения. Если бы все рождающиеся дети выживали, и, в свою очередь, производили потомство, то достаточно было бы двух детей на каждый брак, чтобы поддержать население на том же уровне, а при количестве более двух детей, должно было бы наступить увеличение населения. В действительности, это, конечно, не так, ибо многие умирают в детстве, многие не вступают вовсе в брак. Значит, для воспроизводства того же числа населения, - не говоря уже об его увеличении, - нужно, чтобы каждая супружеская чета, в среднем, производила более двух детей. Этот минимум для Германии, - имея в виду цифры детской смертности и безбрачия, - можно считать в три ребенка, в среднем, на каждую семью. В действительности же, это число составляет сейчас менее двух $(1,9)^{9}$. Иначе говоря, германское население в действительности быстро идет к уменьшению.

Разгадка противоречия этих цифр заключается в том, что германское население довольно быстро увеличивалось вплоть до войны (вследствие быстрого падения смертности, несмотря на некоторое падение рождаемости, - все-таки в XX в., до войны, рождаемость на одну брачную чету составляла 4). Во время же и со времени войны наступило крайне быстрое падение рождаемости. В результате, число молодых людей брачного и «производительного» возраста в германском населении непропорционально велико, по сравнению с детьми и стариками. Поэтому сейчас смертность искусственно понижена, а рождаемость (на все население) искусственно повышена, так как процент лиц, вступающих в брак, очень велик. Когда же нынешние молодые люди состарятся, а их место займут нынешние подростки, значительно менее [много]численные, то смертность повысится, а рождаемость упадет, - как то уже случилось в Англии, где рост населения уже и «формально» остановился.

Так как во Франции рост населения остановился еще до войны, то во французском населении процент стариков гораздо больше и поэтому французская смертность кажется выше германской. Эта разница (18 на тыс. [населения] смертность во Франции, вместо 14 в Германии) объясняется, как признают теперь и немецкие статистики, только высоким процентом стариков во французском населении, а вовсе не отсталыми будто бы санитарными условиями. В действительности, средняя продолжительность жизни француза выше, чем таковая же немца, детская смертность во Франции ниже, чем в Германии. Количество же детей на одну семью во Франции несколько выше. Факт тот, что французское население уже давно начало приспособляться к условиям новой культуры, немецкое же впопыхах приспособляется только теперь. Во Франции можно ожидать очень медленного уменьшения населения, замедляемого миграцией, в Германии это уменьшение пойдет с большой быстротой.

\footnotetext{
9 Цифра приведена согласно расчетам Э. Кана: [Kahn 1930: 12].
} 
Но как же обстоит дело со «славянским наводнением», - в особенности, с «неограниченным человеческим материалом» в России?

Верно то, что в странах Восточной Европы понижение рождаемости до войны было почти незаметным, хотя понижение смертности шло довольно быстро. Тем скорее идет «приспособление» в настоящее время. Опять-таки общие цифры рождаемости и смертности вводят в заблуждение. Если исходит из этих цифр, то процент прироста населения в России составляет сейчас рекордную цифру в 24 на тыс. (рождаемость: 42, против смертности: $18)^{10}$. Но эти цифры объясняются опять-таки огромным процентом молодых людей брачного и «производительного» возраста. В виду этого, рождаемость на все население в России понизилась всего с 45 на тыс. довоенных до 42. В действительности же, понижение плодовитости населения несравненно более значительно. Среднее число детей на один брак в России составляет уже сейчас только три (вместо 5,5 довоенных) ${ }^{11}$, и эта цифра неуклонно понижается из года в год. По мнению Э. Кана, - имея в виду цифру детской смертности в России, более высокую, чем в Германии, - нужно ставить вопрос, не начинается ли уже и в России фактический дефицит населения. Во всяком случае, то огромное количество «рабсилы», которое пока находится, - вернее, находилось, - в распоряжении Сталина, представляет собою чисто временное явление.

Ограничимся пока приведением этих данных. Новейшие методы исчисления развития населения, путем которых получаются эти выводы, вызывают и возражения, также не лишенные оснований. Но не считаться с этими методами, - при их большой ясности, силе и определенности получаемых результатов, - очевидно невозможно. На анализе этих результатов с более общей точки зрения, остановимся как-нибудь в другой раз ${ }^{12}$.

\section{ЛИТЕРАТУРА}

Вишневский А.Г. (2005). Избранные демографические труды. Т. I. М.: Наука. 368 с.

Вишневский А., М. Тольц (2015). Незамеченный вклад в теорию демографического перехода // Демографическое обозрение. 2(4): 6-34. DOI: https://doi.org/10.17323/demreview.v2i4.1767 (дата обращения: 08.02.2018).

Волков А.Г. (2014). Избранные демографические труды. М.: Изд. дом Высшей школы экономики. 567 с.

Демографическая модернизация России, 1900-2000 (2006) / Под ред. А.Г. Вишневского. М.: Новое издательство. 608 с.

${ }^{10}$ См. примечание 7.

11 Здесь автор исходит из цифр в книге Э. Кана [Kahn 1930: 64-65], однако там для 1900 г. показатель равен 5,4. Позднее Р.P. Кучинский на примере для Украины подверг критике эти оценки и показал, что величина показателя для 1929 г. должна быть оценена выше, если принять во внимание распадение брачных союзов: 3,6 рождения на один брак, тогда как расчет Э. Кана давал только 3,1 рождения [Kuczynski 1935: 38]. Отметим, что при отсутствии в его распоряжении данных за 1929 г. Э. Кан принял показатель для всего СССР равным указанной заниженной оценке для Украины за этот год - 3,1 рождения [Kahn 1930: 65].

12 Продолжение цикла в доступных нам номерах газеты «Последние новости» не найдено (возможно, не состоялось). 
Дионео [Шкловский И.В.]. (1928). К добру или к худу? // Последние новости (Париж). 29 января: 2.

Дойков Ю.В. (2004). Самые знаменитые историки России. М.: Вече. 384 с.

Дойков Ю.В. (2009). Питирим Сорокин. Человек вне сезона. Биография. Т. 2. Архангельск. 488 c. URL: http://doykov.com/tag/pitirim-sorokin/ (дата обращения: 08.02.2018).

Кулишер И.М. (2004). История экономического быта Западной Европы. 9-е изд. Челябинск: Социум. 1030 с.

Кулишер М.И. (1887). Очерки сравнительной этнографии и культуры. СПб.: Типография И.Н. Скороходова. 290 с.

Мейснер Д.И. (1966). Миражи и действительность: записки эмигранта. М.: АПН. 298 с.

Псевдонимы русского зарубежья (2016) / Под ред. М. Шрубы, О. Коростелева. М.: НЛО. $656 \mathrm{c}$.

Раев М. (1994). Россия за рубежом: история культуры русской эмиграции. 1919-1939. М.: Прогресс-Академия. 296 с.

Россет Э. (1968). Процесс старения населения. М.: Статистика. 510 с.

Смит А. (2007). Исследование о природе и причинах богатства народов. М.: Эксмо. 1056 с.

Тольц М. (2015). Забытый энциклопедист: Михаил Игнатьевич Кулишер (1847-1919) // Еврейская старина. 2. URL: http://berkovich-zametki.com/Starina0.php?srce=85 (дата обращения: 08.02.2018).

Тольц М. (2017). Первая Всемирная конференция по народонаселению глазами двух русских участников-эмигрантов // Демографическое обозрение. 4(4): 170-190. DOI: https://doi.org/10.17323/demreview.v4i4.7534 (дата обращения: 08.02.2018).

Урланис Б.Ц. (2007). Историческая демография: избранные труды. М.: Наука. 468 с.

Юниус [Кулишер А.М.]. (1927). Куда идет человечество? // Последние новости (Париж). 10 сентября: 3; перепечатано в: Демографическое обозрение. 2017. 4(4): 173-176. DOI: https://doi.org/10.17323/demreview.v4i4.7534 (дата обращения: 08.02.2018).

Юниус [Кулишер А.М.]. (1928). «Вымирание» // Последние новости (Париж). 8 февраля: 2.

Юниус [Кулишер А.М.]. (1931). Цикл населения // Последние новости (Париж). 17 июля: 2.

Юниус [Кулишер А.М.]. (1932). Будущее человечества // Последние новости (Париж). 2 апреля: 3.

Carr-Saunders A.M. (1931). The coming drop in population // The Observer (London). 12 July: 17.

Correspondent. (1931). The decline of the birth rate // The Journal of the American Medical Association. 97(20): 1477-1488.

Cox H. (1922).The problem of population. London: Jonathan Cape. 198 p.

Hodgson D. (1993). Demography as social science and policy science // Population and Development Review. 9(1): 1-34.

Ipsen C. (1996). Dictating demography: the problem of population in Fascist Italy. Cambridge, UK: Cambridge University Press. 281 p. 
Kahn E. (1930). Der Internationale Geburtenstreik: Umfang, Ursachen, Wirkungen,

Gegenmaßnahmen? Frankfurt am Main: Societäts-Verlag. 218 s.

Kuczynski R.R. (1928). The balance of births and deaths. Vol. I: Western and Northern Europe. New York: Macmillan. 170 p.

Kuczynski R.R. (1931). The balance of births and deaths. Vol. II: Eastern and Southern Europe. Washington DC: The Brookings Institution. $140 \mathrm{p}$.

Kuczynski R.R. (1935). The measurement of population growth: methods and results. London: Sidgwick and Jackson. 255 p.

Kulischer A., E. Kulischer (1932). Kriegs- und Wanderzüge. Weltgeschichte als Völkerbewegung. Berlin - Leipzig: Walter de Gruyter. 238 s.

Kulischer E.M. (1948). Europe on the move: war and population changes, 1917-1947. New York: Columbia University Press. 377 p.

Methorst H.W. (1927a). Results of differential birth rate in The Netherlands // Proceedings of the World Population Conference / Sanger M., ed. London: Edward Arnold: 169-190.

Methorst H.W. (1927b). Survey of birth-rates of the World // Eugenic Review. 19(2): 116-127.

Ross E.A. (1909). Changing America. New York: Chautaugua Press. 236 p.

Scifres D. (1964). Consideration of Edward A. Ross as a progressive in the 1920's. Thesis (M.A.). University of Wisconsin - Madison. $194 \mathrm{p}$.

Sutherland A. (1898). The origin and growth of the moral instinct. Vol. 1. London: Longmans, Green, and Co. 461 p.

Szreter S. (1993). The idea of demographic transition and the study of fertility change: a critical intellectual history // Population and Development Review. 19(4): 659-701.

Thompson W.S. (1929). Population // American Journal of Sociology. 34(6): 959-975. 


\title{
ALEXANDER KULISCHER ON THE DEMOGRAPHIC FUTURE OF RUSSIA
}

\section{MARK TOLTS}

\begin{abstract}
At the turn of the 1920s and 1930s, Alexander Kulischer published three demographic articles in the most authoritative and widely read newspaper of the Russian post-revolutionary emigration - "Poslednie novosti" [The Latest News] (Paris). These articles were devoted to problems of population dynamics in some countries around the world. They were the first where the general scheme of demographic changes - now known as the concept of a "demographic transition" or "demographic revolution" - was used in predicting the demographic future of Russia. This publication provides these articles, which are now almost inaccessible to contemporary readers. A preface and helpful explanations have been added to the articles. The preface explains Kulischer's articles in the context of the development of demography of that period and his interest in the demographic future of Russia.
\end{abstract}

Key words: history of demography, demographic transition, demographic revolution, demographic dynamics, fertility, mortality, population of Russia, Alexander Kulischer [Alexandre Koulicher] (1890-1942).

MARK Tolts (mtolts@huji.ac.il), HEbrew UNIVERSITY OF JERUSALEM, ISRAEL.

(PREFACE, PREPARATION OF THE TEXT FOR PUBLICATION AND COMMENTS)

AleXANDER Kulischer [AlEXANDRE KOULICHER] (1890-1942).

DATE RECEIVED : APRIL 2018.

\section{REFERENCES}

Carr-Saunders A.M. (1931). The coming drop in population // The Observer (London). 12 July: 17.

Correspondent. (1931). The decline of the birth rate // The journal of the American Medical Association. 97(20): 1477-1488.

Cox H. (1922). The problem of population. London: Jonathan Cape. 198 p.

Demograficheskaya modernizatsiya Rossii, 1900-2000 [Demographic modernization of Russia, 1900-2000] (2006) / A.G. Vishnevsky, ed. Moscow: Novoye izdatel'stvo [New Publishing House]. 608 p.

Dioneo [Shklovsky I.V.]. (1928). K dobru ili k khudu? [For better or for worse?] // Poslednie novosti [The latest news] (Paris). 29 January: 2.

Doykov Yu.V. (2004). Samyye znamenityye istoriki Rossii [The most famous Russian historians]. Moscow: Veche. 384 p.

Doykov Yu.V. (2009). Pitirim Sorokin. Chelovek vne sezona. Biografiya [Pitirim Sorokin. Man out of season. Biography]. Vol. 2. Arkhangelsk. 488 p. URL: http://doykov.com/tag/pitirimsorokin/ (accessed: 08.02.2018).

Hodgson D. (1993). Demography as social science and policy science // Population and Development Review. 9(1): 1-34.

Ipsen C. (1996). Dictating demography: the problem of population in Fascist Italy. Cambridge, UK: Cambridge University Press. 281 p.

Junius [Kulisher A.M.]. (1927). Kuda idet chelovechestvo? [Where is humankind heading?] // Poslednie novosti [The latest news] (Paris). 10 September: 3; republished in: 
Demograficheskoe obozrenie [Demographic Review]. 2017. 4(4): 173-176. DOI: https://doi.org/10.17323/demreview.v4i4.7534 (accessed: 08.02.2018).

Junius [Kulisher A.M.]. (1928). «Vymiranie» [Extinction] // Poslednie novosti [The latest news] (Paris). 8 February: 2.

Junius [Kulisher A.M.]. (1931). Tsikl naseleniya [Population cycle] // Poslednie novosti [The latest news] (Paris). 17 July: 2.

Junius [Kulisher A.M.]. (1932). Budushcheye chelovechestva [The future of humankind] // Poslednie novosti [The latest news] (Paris). 2 April: 3.

Kahn E. (1930). Der Internationale Geburtenstreik: Umfang, Ursachen, Wirkungen, Gegenmaßnahmen? Frankfurt am Main: Societäts-Verlag. 218 s.

Kuczynski R.R. (1928). The balance of births and deaths. Vol. I: Western and Northern Europe. New York: Macmillan. 170 p.

Kuczynski R.R. (1931). The balance of births and deaths. Vol. II: Eastern and Southern Europe. Washington DC: The Brookings Institution. $140 \mathrm{p}$.

Kuczynski R.R. (1935). The measurement of population growth: methods and results. London: Sidgwick and Jackson. 255 p.

Kulischer A., E. Kulischer (1932). Kriegs- und Wanderzüge. Weltgeschichte als Völkerbewegung. Berlin - Leipzig: Walter de Gruyter. 238 s.

Kulischer E.M. (1948). Europe on the move: war and population changes, 1917-1947. New York: Columbia University Press. 377 p.

Kulischer I.M. (2004). Istoriya ekonomicheskogo byta Zapadnoy Evropy [History of economic life in Western Europe]. 9th ed. Chelyabinsk: Sotsium. 1030 p.

Kulischer M.I. (1887). Ocherki sravnitel'noy etnografii i kul'tury [Essays on comparative ethnography and culture]. St. Petersburg: Tipografiya I.N. Skorokhodova [Print shop I.N. Skorokhodov]. 290 p.

Meisner D.I. (1966). Mirazhi i deystvitel'nost': zapiski emigranta [Mirages and reality: notes of an émigré]. Moscow: APN. 298 p.

Methorst H.W. (1927a). Results of differential birth rate in The Netherlands // Proceedings of the World Population Conference / Sanger M., ed. London: Edward Arnold: 169-190.

Methorst H.W. (1927b). Survey of birth-rates of the World // Eugenic Review. 19(2): 116-127.

Psevdonimy russkogo zarubezh'ya [Pseudonyms of the Russian Diaspora] (2016) / M. Schruba, O. Korostelev, eds. Moscow: NLO. 656 p.

Raeff M. (1994). Rossiya za rubezhom: istoriya kul'tury russkoy emigratsii. 1919-1939 [Russia abroad: a cultural history of the Russian emigration. 1919-1939]. Moscow: ProgressAkademiya. 296 p.

Ross E.A. (1909). Changing America. New York: Chautaugua Press. 236 p.

Rosset E. (1968). Protsess stareniya naseleniya [Aging process of population]. M.: Statistika. 510 p.

Scifres D. (1964). Consideration of Edward A. Ross as a progressive in the 1920's. Thesis (M.A.). University of Wisconsin - Madison. 194 p.

Smith A. (2007). Issledovanie o prirode i prichinakh bogatstva narodov [An inquiry into the nature and causes of the wealth of nations]. Moscow: Eksmo. 1056 p. 
Sutherland A. (1898). The origin and growth of the moral instinct. Vol. 1. London: Longmans, Green, and Co. 461 p.

Szreter S. (1993). The idea of demographic transition and the study of fertility change: a critical intellectual history // Population and Development Review. 19(4): 659-701.

Thompson W.S. (1929). Population // American Journal of Sociology. 34(6): 959-975.

Tolts M. (2015). Zabytyy entsiklopedist: Mikhail Ignat'evich Kulisher [A forgotten polymath: Mikhail I. Kulischer] (1847-1919) // Yevreyskaya starina [Jewish antiquity]. 2. URL: http://berkovich-zametki.com/Starina0.php?srce=85 (accessed: 08.02.2018).

Tolts M. (2017). Pervaya vsemirnaya konferentsiya po narodonaseleniyu glazami dvukh russkikh uchastnikov-emigrantov [The first world population conference through the eyes of two Russian emigrant participants] // Demograficheskoe obozrenie [Demographic Review]. 4(4): 170-190. DOI: https://doi.org/10.17323/demreview.v4i4.7534 (accessed: 08.02.2018).

Urlanis B.Ts. (2007). Istoricheskaya demografiya: izbrannye trudy [Historical demography: selected works]. Moscow: Nauka. 468 p.

Vishnevsky A.G. (2005). Izbrannye demograficheskie trudy [Selected demographic works]. Vol. I. Moscow: Nauka. 368 p.

Vishnevsky A., M. Tolts (2015). Nezamechennyy vklad v teoriyu demograficheskogo perekhoda [An unnoticed contribution to demographic transition theory] // Demograficheskoe obozrenie [Demographic Review]. 2(4): 6-34. DOI: https://doi.org/10.17323/demreview.v2i4.1767 (accessed: 08.02.2018).

Volkov A.G. (2014). Izbrannyye demograficheskiye trudy [Selected demographic works]. Moscow: Izd. dom Vysshey shkoly ekonomiki [HSE Publishing House]. 567 p. 